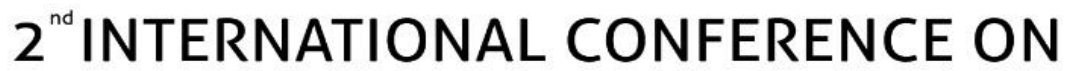 FUTURE OF TEACHING \& EDUCATION
}

\author{
Munich,Germany
}

6 - 8 December,2019

\section{Pakistan Higher Education System (Policies \& Reforms)}

\author{
Irshad Ahmad \\ Mukammil shah \\ Research Officer at Community Development Organization Pakistan \\ Program Director \& Research Officer De Laas Gul welfare Program Pakistan
}

\begin{abstract}
Education assumes an import job in the advancement and improvement of a state. Advancement of any nation relies on its proficiency rate and nature of instruction in that nation. In this way, it is the key needs of countries. Sadly, our own nation Pakistan is a regressive one with respect to its proficiency rate. Indeed, even numerous poor nations have higher education rate as contrast with Pakistan. Our policy framework and priority is in charge of this. Higher education has incredible significance in the improvement of a nation. Be that as it may, sadly, its significance is yet to be acknowledged in Asian nations. For over 70 years, Pakistan have been attempting to inspire their instructive standard by giving quality advanced education to their natives yet there are numerous deterrents and obstacles that are rising. These difficulties (amount, value, quality, and so on) are exceptionally normal in nature however require appropriate methodology to address in the best way. The study explain on major initiatives in higher education institutions in Pakistan according to experts, likewise investigates the job of Higher Education Commission (HEC) of Pakistan in presenting these changes. By utilizing subjective research technique the examination embraces an illustrative research way to deal with present an all-encompassing perspective on the key change activities in HEIs both as far as substance and procedure, study highlights the major issues, policies, challenges and reforms in higher education of Pakistan in the minds of University professors from public and private sectors.
\end{abstract}

Keywords: Higher Education Commission (HEC), policy framework, amount, value, quality 